\title{
CORRESPONDENCE
}

\section{FAUNAL REALMS IN JURASSIC AND CRETACEOUS BELEMNITES}

SIR,-I am sorry Dr. R. Bowen (Geol. Mag., 101, 1964, 374-6) has adopted such a polemical approach to the problem of Mesozoic faunal realms, for their understanding will benefit from all types of data, including the isotope temperature studies for which he has been responsible. It is too early to be dogmatic and I must apologize if my paper (Stevens, 1963) seemed so. Space limitation prevented full treatment of belemnite faunal realms in my paper, but greater detail is provided in Stevens, 1965, pp. 168-189.

As indicated in my paper (1963), the concept of Mesozoic faunal realms or provinces, similar to those of the present-day oceans, but on a broader scale, is not new (Arkell, 1956; Donovan, 1957, pp. 147-8, 155-7) and, furthermore, is not based on belemnite studies alone. Uhlig (1911) and Arkell (1956) recognized a number of Jurassic faunal realms, the majority closely comparable to those distinguishable from belemnite distribution. The differences can perhaps be accounted for by differences in inferred habitats of belemnites (dominantly shelf inhabitants, neritic) and ammonites (free swimming, nektonic). The faunal realms proposed by Uhlig and Arkell were both based on palaeobiogeographic observations built up over a lifetime of experience in palaeontology and stratigraphy. The Boreal realm recognized in belemnites (which Bowen questions before the later Cretaceous) is essentially that recognized by Uhlig, Arkell, and other workers (e.g. Donovan, 1957, pp. 147-8, 155-7; Gustomesov, 1956, 1961, 1964; Naidin, 1954, 1959). Palaeontologists, I think, will agree that a distinctive Boreal realm existed in the Jurassic, and the point at issue is rather whether its distinctness resulted from climatic zoning. Other workers have concluded that the delimitation of the Jurassic and Cretaceous Boreal realm is the result of climatic zoning. Furthermore, as stated by Arkell (1956, pp. 615-8), faunal studies suggest that the Boreal seas were not particularly cold, i.e. the temperature difference between Boreal and Tethyan faunas was probably comparable to the difference between temperate and sub-tropical zones.

Other workers (e.g. Uhlig, 1911) have recognized a number of realms (e.g. Mediterranean, Himamalayan, South Andine) besides the Jurassic Boreal realm, but in my opinion the belemnite palaeobiogeographical data for the Jurassic can be best presented in terms of two additional major realms, Tethyan and Indo-Pacific. Whilst the Boreal-Tethyan boundary is thought of as probably climatic, the Tethyan-Indo-Pacific boundary cannot be thus interpreted so that physical palaeogeographic barriers seem likely (see Stevens, 1963, 1965, pp. 182-9). This essential difference between the two boundaries is an important part of my hypothesis to explain belemnite distribution in the Jurassic. My hypothesis that deep water barriers, operating sporadically, were primarily responsible for the observed differences between the Jurassic Tethyan and Indo-Pacific belemnites may not be correct, but some such hypothesis is necessary to interpret the observed differences between Tethyan and Indo-Pacific faunas in an area where it is agreed there is no evidence of climatic barriers. On the other hand, the relative stability of the BorealTethyan boundary from Jurassic to Cretaceous in Europe and its rough alignment with present latitudinal boundaries (Stevens, 1963, Text-figs 3-6) supports the climatic control hypothesis. Differentiation of present day marine faunas in response to climate is complex. Many tropical faunas grade imperceptibly into temperate faunas and though the separate faunas may be readily distinguished there are no exact boundaries. Thus we cannot expect exact boundaries to be drawn on palaeobiogeographic maps. The boundaries are biological ones, where limited intermingling of faunas is to be expected, but this does not deny their existence (cf. Schenck and Keen, 1940).

The Indo-Pacific realm of the Jurassic and Neocomian apparently differed from that of Aptian-Maestrichtian times. Prior to the Aptian the Indo Pacific realm was evidently an offshoot of the Tethyan realm (Stevens, 1963, 
p. 481). Intercommunication of belenmites between these realms does not necessarily imply a eurythermal habitat (Bowen's letter p. 375), but simply that no climatic barriers existed to prevent migration, providing seaway connections were available. This situation changed in the Aptian, when Dimitobelinae appeared in the Indo-Pacific region; thereafter only limited intermingling occurred (e.g. Southern India and New Guinea) between the Dimitobelinae and the Tethyan fauna. As suggested in my paper, the Dimitobelinae may have been restricted to an "Austral " zone, cooler than the Tethyan zone, but this is merely a working hypothesis.

Denial of faunal realms prior to the later Cretaceous has led to lumping of elements from distinct faunas in Bowen's interpretations of palaeotemperatures, e.g. in the Albian (Bowen, 1961c): Neohibolites from France and Japan, Parahibolites from India, Dimitobelus from Australia. It has also led to statements such as Bowen's (1961, p. 82): "In the Cretaceous Belemnoids were quite widespread prior to the Cenomanian, but then and thereafter, there took place a northward retreat of these organisms-interpreted as due to a change in their living habits from eurythermal to stenothermal ..." (see also Lowenstam and Epstein, 1954, p. 246). Boreal belemnites existed well before the Cenomanian and the Cenomanian Belemnitellinae simply took over the ecological niche vacated by the Lower Cretaceous Boreal assemblage (Oxyteuthinae and before them, Pachyteuthinae).

I stated clearly (1963, p. 491) that the available oxygen isotope analyses gave no support for the hypothesis that the Jurassic Boreal and Tethyan realms shown by faunas were primarily a result of climatic differences, believing it better to admit that there is as yet no agreement, than to attempt to make the limited data fit by postulating cold (or warm) currents (e.g. Lowenstam and Epstein, 1959, p. 75), a change of habit during the life of the belemnites (e.g. eurythermal to stenothermal, or living in deep water and dying in shallow water) or by casting doubt on inconsistent determinations in some other way. In my opinion the palaeobiogeographical bases for the faunal realms are founded on reasonably adequate sampling, whereas it will be some time before we can say the same about the Jurassic oxygen isotope determinations.

In the matter of faunal realms we are still in the stage of erecting hypotheses and testing them with new data, both isotopic and palaeobiological. For example, to test the hypothesis that the Boreal-Tethyan boundary is a climatic gradient it may be possible to "erect an experiment" in an area where both realms are in contact (e.g. Upper Jurassic of U.S.S.R., see Gustomesov, 1956, 1961) and subject the belemnites from each to detailed isotopic analysis.

Bowen criticizes the hypothesis that Liassic climates, judged by the universality of Liassic ammonites and belemnites, were almost uniform, but in one of the references used to support his criticism (Bowen, 1963a) he quotes the universality of Liassic ammonites to support " a considerable uniformity of temperature ... throughout Western Europe in Liassic times ", based on analyses of thirteen specimens, hardly representative of the 10 to 15 million years spanned by the Lias. Yet, shortly afterwards (Bowen and Fritz, 1963), and in his letter (p. 374) he shows "... that the Lias, at least in Germany, is very diverse temperaturewise ". Obviously many more determinations are needed before the isotope data can give a consistent picture.

Bowen has commented on my failure to recognize an undoubted Southern Hemisphere equivalent of the Jurassic Boreal realm owing to scarcity of belemnites in South Africa and South America. Though I have examined Jurassic material from South America, including some from the localities of Bowen's (unidentified) specimens (Bowen, 1963), they are from few localities and horizons, and not adequately representative of such an area. Furthermore, Bowen's South American results are from the Lias and Bajocian, when faunal realms were not in evidence. His earlier $(1961 b$, p. 311$)$ determinations of Upper Jurassic specimens from Argentina would be relevant, if the specimens were identified and their age more certain; as it is they may apply either to the Indo-Pacific element (strongly evident in the Upper Jurassic of 
southern South America) or to the endemic Belemnopsis whose presence I commented on in my paper. Many of Bowen's other determinations are from unidentified belemnites, so that if the assemblage is a mixed one it is difficult or impossible to assign the belemnites used to any particular biogeographical realm. The temperature determined may represent the lower limit of the temperature range of a warm-water form, or alternatively the upper limit of a cool-water form, if the region is one in which overlap of both forms occurs. Therefore in compiling tables of temperature determinations (Stevens, 1965, Table 19, pp. 185-7) certain assumptions have to be made for their interpretation.

Bowen criticizes my statement (Stevens, 1963, p. 493) that "while the available belemnite evidence supports the postulate of a gradual temperature decline in the Upper Cretaceous there is no support for temperature maxima in the Coniacian-Santonian and Albian ". But if the end-Cretaceous climatic deterioration, shown so markedly in the distribution of belemnites, as well as other fossils (Lowenstam and Epstein, 1954, p. 245), is shown only by a temperature trend such as that depicted in Bowen's graph $(1961$, p. 82) then the effects on world faunas would surely be even more marked for the fluctuations he has shown (low in the Cenomanian, highs in the Albian and Coniacian-Santonian) which are of far greater amplitude. As far as I am aware the effects of these fluctuations have not yet been detected in contemporary faunas. Small-scale climatic fluctuations throughout this time, such as that shown from the Aptian-Albian of Australia (see Stevens, 1965, Table 19, pp. 185-7) were apparently not faunally significant. Future detailed work on faunal distributions will help resolve this question.

Early oxygen isotope results were interpreted with caution as many biological factors (depth ranges, threshold limits of shell synthesis for given species, etc., cf. Bé and Ericson, 1963, p. 78) remain uncertain and will always be so for extinct organisms such as belemnites. Moreover, variation in results due to physical effects, such as diagenesis, salinity variations, etc., may be such that a temperature difference of $7^{\circ} \mathrm{C}$. drawn attention to by Bowen (letter, p. 375) may fall within the variation limits of the method and so have little real significance. Lowenstam and Epstein (1954, p. 208; see also Lloyd, 1964) have commented on the possibility of a variation of $3^{\circ}$ to $4^{\circ} \mathrm{C}$. due to salinity effects, an idea summarily dismissed by Bowen $(1961 a$, p. $771 ; 1961 b$, p. 315 ) and Bowen himself $(1961 \mathrm{c}, \mathrm{p} .1081)$ has measured variations of $2^{\circ}$ to $8^{\circ} \mathrm{C}$., with sometimes a range of $12^{\circ} \mathrm{C}$. in a single individual. Therefore, without many more determinations than are presently available and perhaps without some type of statistical treatment, to establish acceptable variation limits, it is unwise for palaeoclimatologists at this juncture to give undue emphasis to oxygen isotope determinations, at the expense of soundly-based palaeobiogeographical observations.

New Zealand Geological Survey, G. R. Stevens.

\author{
P.O. Box 368, \\ LOWER HUTT, \\ NeW ZEALAND.
}

20 th January, 1965.

\title{
REFERENCES
}

Arkell, W. J., 1956. Jurassic Geology of the World. Edinburgh and London. BÉ, A. W. H., and D. B. ERICSON, 1963. Aspects of Calcification in Planktonic Foraminifera (Sarcodina). Ann. N.Y. Acad. Sci., 109, 65-81.

Bowen, R., 1961. Paleotemperature analyses of Mesozoic Belemnoidea from Germany and Poland. J. Geol., 69, 75-84.

1961a. Paleotemperature analyses of Mesozoic Belemnoidea from Australia and New Guinea. Bull. geol. Soc. Amer., 72, 769-774.

$1961 b$. Paleotemperature analyses of Belemnoidea and Jurassic Paleoclimatology. J. Geol., 69, 309-320. 
1961c. Oxygen isotope paleotemperature measurements on Cretaceous Belemnoidea from Europe, India and Japan. J. Paleont., 35, $1077-1084$.

1963. $\mathrm{O}^{18} / \mathrm{O}^{16}$ Paleotemperature Measurements on Mesozoic Belemnoidea from Neuquén and Santa Cruz Provinces, Argentina. J. Paleont., 37, 714-8.

1963a. Oxygen Isotope Paleotemperature Measurements on Lower Jurassic Belemnoidea from Bamberg (Bavaria, Germany). Experientia, 19, 401.

and P. Fritz, 1963. Oxygen Isotope Paleotemperature Analyses of Lower and Middle Jurassic Fossils from Pliensbach, Württemberg (Germany). Experimentia, 19, 461-5.

Donovan, D. T., 1957. The Jurassic and Cretaceous Systems in East Greenland. Medd. Gronland, 155 (4).

Gustomesov, V. A., 1956. Ecology of the belemnites of the Upper Jurassic of the Russian platform (in Russian). Bull. Soc. Nat. Moscow, Geol. Ser., 31, 113-4.

1961. On the Ecology of Upper Jurassic Belemnites (in Russian). Trudy Mosk. Geol.-Prospect. Inst., 37, 190-204.

1964. Boreal Late Jurassic Belemnites (Cylindroteuthinae) of the Russian Platform (in Russian). Trudy Geol, Inst. Akad. Nauk. S.S.S.R. Moscow, 107, 91-220.

LloYd, R. M., 1964. Variations in the Oxygen and Carbon Isotope Ratios of Florida Bay Mollusks and their Environmental Significance. J. Geol., 72, 84-111.

Lowenstam, H. A., and S. Epstein, 1954. Paleotemperatures of the postAptian Cretaceous as determined by the oxygen isotope method. J. Geol., 62, 207-48.

1959. Cretaceous paleotemperatures as determined by the oxygen isotope method, their relations to and the nature of Rudistid reefs. 20th Cong. Geol. Internac., Symp. "El Sistema Cretacico," 1, 65-76.

NaIDin, D. P., 1954. Some distributional limits of European Upper Cretaceous belemnites (in Russian). Bull. Soc. Nat. Moscow, Geol. Ser., 29, 19-28.

1959. On the Palaeogeography of the Russian platform during the Upper Cretaceous epoch. Stockholm Contrib. Geol., 3, 127-138.

SCHENCK, H. G., and A. M. KeEN, 1940. Biometrical Analysis of Molluscan Assemblages. Soc. Biogéographie Contr. 7 a l'étude de la répartition actuelle et passée des organismes dans la zone néritique, 379-392.

Stevens, G. R., 1963. Faunal Realms in Jurassic and Cretaceous belemnites. Geol. Mag., 100, 481-497.

1965. The Jurassic and Cretaceous belemnites of New Zealand and a review of the Jurassic and Cretaceous belemnites of the IndoPacific region. N. Z. geol. Surv. palaeont. Bull., 36.

Uhlig, V., 1911. Die marinen Reiche des Jura und der Unterkreide. Mitt. geol. Ges, Wien, 4, 329-448.

\section{THE " RED ROCK FAULT"}

SIR,-Along many lines separating the outcrops of Triassic (or PermoTriassic) from older rocks in England faults are frequently mapped and incorporated in the written records. In most of these instances such a fault does not, on the face of it, appear to be necessary to explain the observed facts, and as a general unconformity at the base of the Trias is already universally acknowledged, the burden of proof lies on those who affirm the existence of a fault, not on those who deny it. The purpose of this letter is to draw attention to such "faults", often boldly drawn, along the margins of coalfields, and of these there is probably none so firmly entrenched in the literature as that along the western edge of the North Staffordshire coalfield, and further northwards, between the Carboniferous rocks on the east and the 